\title{
Lipid profile in a group of patients with Turner's syndrome at Clínica Universitaria Bolivariana in the Medellín city between 2000 and 2009*
}

\author{
Eduar Valencia, MD' ${ }^{1}$, Lina María Serna, MD², Lina María Betancur, MD², \\ Carlos Mauricio Medina, MD², Álvaro Arango, MD ${ }^{3}$
}

\section{SUMMARY}

Introduction: Turner syndrome patients can present lipid profile alterations, which associated with obesity, frequent in these patients, causes increased cardiovascular risk, lowering their life expectancy. This research evaluates lipid profiles of patients with Turner syndrome between 2000 and 2009 and these are associated to the karyotype and other risk factors for coronary disease.

Objective: To describe the lipid profile and other cardiovascular risk factors in a group of girls with Turner syndrome.

Methods: This is a descriptive study, which evaluated the clinical records of 21 girls with Turner syndrome. We sought metabolic risk factors for coronary disease such as lipid profile, weight, body mass index, and blood pressure.

Results: Age at time of diagnostics ranged between 8 months to 17 years, four patients were below 10 years of age and 17 patients were over 11 years of age. The karyotype revealed: $57.3 \%$ with $45 \mathrm{x}$ monosomy, $33 \%$ with $46 \mathrm{xx}-45 \mathrm{x}$ mosaicism, and $9.5 \%$ with 46x-qx mosaicism. None of the patients was obese; the total cholesterol levels ranged from $116 \mathrm{mg} / \mathrm{dl}$ to 225 $\mathrm{mg} / \mathrm{dl}$ with a mean of 168.7 . When these patients were grouped by age, we found that $25 \%$ of those younger than 10 years of age had high levels of cholesterol vs. $58.8 \%$ for those over 10 years of age. Regarding the karyotype of the six patients with 46xx-45x karyotype, five (71.4\%) presented hypercholesterolemia; 95.2\% of the patients were normotensive.

Discussion: This research revealed Turner syndrome patients present lipid profile alterations at early ages.

Conclusion: It is important to include in the follow up protocol in these patients the lipid profile control and, thus, be able to conduct early interventions to improve their quality of life.

Keywords: Turner's syndrome; Lipid profiles; Obesity; Karyotype; Arterial hypertension; Cholesterol; Triglycerides.

Colomb Med. 2011; 42: 54-60

Perfil lipídico en un grupo de pacientes con síndrome de Turner en la Clínica Universitaria Bolivariana de la ciudad de Medellín entre los años 2000-2009

\section{RESUMEN}

Introducción: Las pacientes con síndrome de Turner (ST) pueden presentar alteraciones en el perfil lipídico, lo que, asociado con la obesidad, frecuente en estas pacientes, produce un aumento del riesgo cardiovascular y reduce su esperanza de vida. En este estudio se evalúan los niveles de perfil lipídico en pacientes con ST entre 2000-2009, y se asocia con el cariotipo y otros factores de riesgo para enfermedad coronaria.

Objetivos: Describir el perfil lipídico en un grupo de niñas con ST y otros factores de riesgo cardiovascular.

Metodología: Estudio descriptivo en el que se evaluaron las historias clínicas de 21 niñas con ST. Se buscaron factores de riesgo metabólico para enfermedad coronaria tales como perfil lipídico, peso, índice de masa corporal y cifras de presión

* Study funded by Universidad Pontificia Bolivariana. The study was conducted at Clínica Bolivariana, Medellín, Colombia.

1. Pediatrician, Professor Universidad Pontificia Bolivariana, Pediatrics Section, Medellín, Colombia.

e-mail: eduarvap@yahoo.es

2. Pediatrics Resident, Universidad Pontificia Bolivariana, Medellín, Colombia. e-mail: lm.serna@hotmail.com lina_b16@hotmail.com copybo@hotmail.com

3. Pediatric Endocrinologist, Professor Universidad Pontificia Bolivariana, Medellín, Colombia. e-mail: calamar1@une.net.co Received for publication February 23, 2010 Accepted for publication August 17, 2010 
arterial.

Resultados: En el momento del diagnóstico la edad osciló entre los 8 meses y 17 años; cuatro pacientes eran menores de 10 años y 17 mayores de 11 años. El cariotipo fue: $57.3 \%$ con monosomía $45 \mathrm{x}, 33 \%$ mosaicismo $46 \mathrm{xx}-45 \mathrm{x}$ y $9.5 \%$ mosaicismo $46 \mathrm{x}$-qx. Ninguna paciente presentó obesidad; los niveles de colesterol total oscilaron entre 116 $\mathrm{mg} / \mathrm{dl}-225 \mathrm{mg} / \mathrm{dl}$ con una media de 168.7. Al agrupar estas pacientes por edad, se encontró que $25 \%$ de las menores de 10 años tenían niveles altos de colesterol vs. $58.8 \%$ de las mayores de 10 años. En relación con el cariotipo de las 6 pacientes con cariotipo $46 \mathrm{xx}-45 \mathrm{x}, 5$ (71.4\%) presentaron hipercolesterolemia; $95.2 \%$ eran normotensas.

Discusión: Este estudio demostró que las pacientes con ST presentan alteración en su perfil lipídico desde edades tempranas.

Conclusión: Es importante incluir en el protocolo de seguimiento de estas pacientes el control del perfil lipídico y así poder realizar intervenciones tempranas y poder mejorar su calidad de vida.

Palabras clave: Sindrome de Turner; Perfil lipídico; Obesidad; Cariotipo; Hipertensión arterial; Colesterol; Triglicéridos.

Colomb Med. 2011; 42: 54-60

Turner syndrome (TS) is one of the most common chromosomal anomalies, affecting approximately $3 \%$ of fetuses and, of these, only $1 \%$ survives. It is responsible for $7-10 \%$ of spontaneous abortions ${ }^{1}$; its rate of occurrence is 1:2000 live births ${ }^{2}$. This pathology is mainly caused by a monosomy of the X chromosome, through partial or complete loss of the second $\mathrm{X}$ chromosome or, in a lower percentage, through cell line mosaicism $^{1}$; this happens because of a failure in the sexual chromatin separation during meiosis in the gametocyte or during an early stage of embrionary division.

Clinically, the syndrome characterized by low stature (approximately $20 \mathrm{~cm}$ below average), micrognathia, low hairline, high-arched palate, crowded teeth, short webbed neck, shortened fourth metacarpal, cavitus valgus, Madelung deformity, hyperconvex nails, increased inter-mammary space (teletelia), scoliosis, congenital hip dysplasia, osteoporosis, lymphedema, gonadal failure, horseshoe kidney ${ }^{3}$, and cardiac anomalies like: coarctation of the aorta, bicuspid aortic valve, anomalous venous drainage, and mitral valve prolapse $e^{4,5}$. In the long term, these patients may present other types of complications like ischemic coronary disease, where it has been found that these patients have twice the risk compared to the normal population and seven times greater risk of mortality, reducing their life expectancy by 6 to 13 years ${ }^{5-8}$.

Patients with ST get medical care during childhood, but most are released by the specialist when they reach their final stature; thereby, disregarding early detection of cardiovascular risk factors that lead to greater morbidity and mortality risk. Due to the aforementioned, long-term monitoring of these patient is necessary, controlling cardiovascular risk factors like blood pressure, lipid profile, glycemia, and early intervention; said control may reduce morbidity and increase life expectancy ${ }^{1}$.

To date, there are no studies in the city of Medellín to justify this control. For this motive, these exams are not routinely performed in these patients. The objective of this study is to describe the behavior of the lipid profile in a group of girls and female adolescents with Turner syndrome in the Medellín.

\section{METHOD}

This descriptive study evaluated the clinical records of 21 women with Turner Syndrome, who had attended pediatric endocrinology consultation at the Clínica Universitaria Bolivariana in the city of Medellín, Colombia, during a period between the years 2000 to 2009; patients without karyotype were excluded. We looked for metabolic risk factors in these women for coronary disease like lipid profile, weight, body mass index (BMI), and blood pressure readings (BP), in addition to the use of estrogens. This study was approved by the Clinic's Research Committee and did not require evaluation by the ethics committee, given that it was considered a low-risk study. The statistical analysis was conducted with the SPSS program.

\section{RESULTS}

We were able to identify 21 patients diagnosed for TS who consult the Clínica Universitaria Bolivariana in the city of Medellín; their ages at the time of diagnosis ranged between 8 months and 17 years and, currently, they are between 8 and 20 years of age; four patients 
Table 1

Patients evaluated with anthropometric indicators and lipid profile

\begin{tabular}{|c|c|c|c|c|c|c|c|c|c|c|c|}
\hline \multirow[b]{2}{*}{ Patient } & \multirow[b]{2}{*}{ Age } & \multirow[b]{2}{*}{ Weight } & \multirow[b]{2}{*}{ Height } & \multicolumn{5}{|c|}{ Anthropometric data and lipid profile } & \multirow[b]{2}{*}{ HDL } & \multirow[b]{2}{*}{$\begin{array}{c}\text { Hypo- } \\
\text { thyroidism }\end{array}$} & \multirow[b]{2}{*}{$\begin{array}{c}\text { Controlled } \\
\text { hypothyroidism }\end{array}$} \\
\hline & & & & BMI & \%BMI & $\begin{array}{c}\text { Total } \\
\text { cholesterol }\end{array}$ & Triglycerides & LDL & & & \\
\hline 1 & 8 & 22.5 & 1.216 & 15.3 & 15 & 189 & 99 & 135 & 34 & No & NA \\
\hline 2 & 8 & 18.0 & 1.11 & 14.5 & 15 & 162 & 44 & 80 & 73 & No & NA \\
\hline 3 & 9 & 32.0 & 1.3 & 18.9 & 85 & 168 & 110 & 100 & 46 & No & NA \\
\hline 4 & 10 & 26.0 & 1.219 & 17.49 & 50 & 157 & 97 & 82 & 55 & No & NA \\
\hline 5 & 11 & 32.0 & 1.428 & 15.69 & 3 & 138 & 72 & 74 & 50 & No & NA \\
\hline 6 & 11 & 27.0 & 1.231 & 17.81 & 50 & 116 & 137 & 41 & 46.8 & YES & YES \\
\hline 7 & 11 & 36.0 & 1.373 & 19.09 & 50 & 149 & 74 & 88 & 45.6 & No & NA \\
\hline 8 & 12 & 37.0 & 1.34 & 20.6 & 85 & 174 & 70 & 100 & 60 & No & NA \\
\hline 9 & 12 & 35.1 & 1.293 & 21.0 & 50 & 150 & 152 & 63 & 56 & YES & YES \\
\hline 10 & 13 & 35.0 & 1.397 & 17.93 & 15 & 185 & 61 & 113 & 60 & No & NA \\
\hline 11 & 13 & 41.9 & 1.43 & 20.48 & 50 & 198 & 55 & 140 & 47 & YES & YES \\
\hline 12 & 14 & 30.0 & 1.369 & 16.0 & 3 & 180 & 119 & 78 & 62 & No & NA \\
\hline 13 & 14 & 43.5 & 1.459 & 20.4 & 50 & 193 & 227 & 93 & 54 & No & NA \\
\hline 14 & 14 & 28.5 & 1.38 & 14.92 & 3 & 180 & 119 & 78 & 62 & No & NA \\
\hline 15 & 15 & 32.0 & 1.393 & 16.49 & 3 & 150 & 64 & 83 & 54 & No & NA \\
\hline 16 & 15 & 35.0 & 1.39 & 18.08 & 15 & 153 & 70 & 91 & 48 & No & NA \\
\hline 17 & 16 & 50.5 & 1.51 & 22.08 & 50 & 192 & 58 & 138 & 42 & YES & YES \\
\hline 18 & 16 & 52,5 & 1.523 & 22.63 & 50 & 142 & 68 & 85 & 44 & No & NA \\
\hline 19 & 16 & 43.0 & 1.52 & 18.61 & 15 & 128 & 107 & 81 & 26 & No & NA \\
\hline 20 & 18 & 40.0 & 1.402 & 20.34 & 25 & 178 & 169 & 104 & 40 & No & NA \\
\hline 21 & 20 & 61.5 & 1.61 & 23.72 & 50 & 225 & 125 & 123 & 87.7 & No & NA \\
\hline
\end{tabular}

NA: Not applicabl

were under 10 years of age (19.4\%) and 17 patients were older than 11 years of age $(80.6 \%)$.

In all the patients assessed, their diagnosis was corroborated with the karyotype; these were distributed thus: 12 patients with $45 \mathrm{x}$ monosomy $(57.3 \%), 7$ patients with 46xx-45x mosaicism (33\%), and 2 patients with 46x-qx mosaicism (9.5\%).

Regarding anthropometric measurements, it was noted that 10 patients $(47.6 \%)$ were slim, i.e., they were within the $3^{\text {rd }}$ to $49^{\text {th }}$ percentile of the body mass index (BMI), 9 patients $(42.8 \%)$ had a BMI between the $50^{\text {th }}$ and $84^{\text {th }}$ percentiles, and two patients $(9.5 \%)$ were overweight with BMI in the $85^{\text {th }}$ percentile; none of the patients was obese.

With respect to lipid profile, we found measurements for $100 \%$ (21) of the patients (Table 1); total cholesterol levels ranged from $116 \mathrm{mg} / \mathrm{dl}$ to $225 \mathrm{mg} / \mathrm{dl}$ with a mean of $168.7( \pm 25.8 \mathrm{mg} / \mathrm{dl}) ; 47.6 \%$ (10 patients) had levels considered high for their age $(>170 \mathrm{mg} / \mathrm{dl})$ and $52.3 \%$ (11 patients) had lower values (Graphic 1). Upon grouping these patients by age, we found that $25 \%$ of the patients younger than 10 years of age had high cholesterol levels $v s .58 .8 \%$ (10 patients) of the patients who were older than 10 years of age. Triglyceride levels ranged between $44 \mathrm{mg} / \mathrm{dl}$ and $227 \mathrm{mg} / \mathrm{dl}$ with a mean of $99.85 \mathrm{mg} / \mathrm{dl}( \pm 46.12 \mathrm{mg} / \mathrm{dl})$; in three patients $(14.2 \%)$, all older than 10 years of age, we found high triglyceride levels ( $>150 \mathrm{mg} / \mathrm{dl})$. Values for HDL and LDL ranged between $26 \mathrm{mg} / \mathrm{dl}$ and $87.7 \mathrm{mg} / \mathrm{dl}$ and $41 \mathrm{mg} / \mathrm{dl}$ and 140 $\mathrm{mg} / \mathrm{dl}$, respectively. The means were $47.06 \mathrm{mg} / \mathrm{dl}$ for HDL and $140 \mathrm{mg} / \mathrm{dl}$ for LDL. Results for HDL were distributed in the following manner: two patients (11.7\%) had HDL levels below $40 \mathrm{mg} / \mathrm{dl}$ (26 and $34 \mathrm{mg}$ / 
dl), 13 patients $(61.9 \%)$ had values between 40 and $60 \mathrm{mg} / \mathrm{dl}$, and six patients $(28.5 \%)$ had values above $60 \mathrm{mg} / \mathrm{dl}$. Again, when grouped by age, no difference was found relating to $\mathrm{HDL}$ $(52 \mathrm{mg} / \mathrm{dl})$; in turn, when associating age to LDL levels we found four patients $(19 \%)$ older than 10 years of age presenting levels above $110 \mathrm{mg} / \mathrm{dl}(113,140$, 138 , and $123.7 \mathrm{mg} / \mathrm{dl}), v s$. one patient $(4.7 \%)$ younger than 10 years of age at $135 \mathrm{mg} / \mathrm{dl}$. Another parameter evaluated was the presence or non-presence of hypothyroidism, finding that four (19\%) of the 21 patients presented this associated pathology; the four patients were adequately controlled.

When relating total cholesterol levels to karyotype, we found: for the $45 \mathrm{x}$ karyotype,

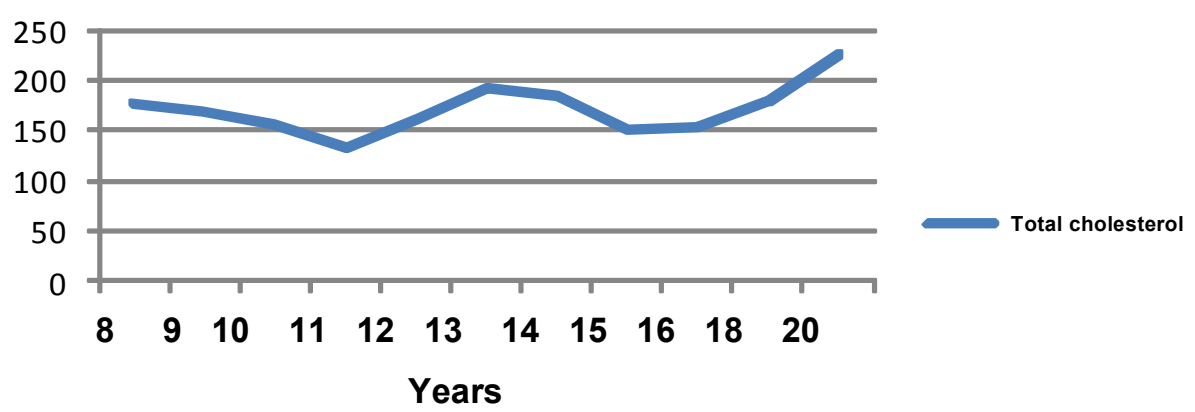
$58 \%$ ( 7 patients) had levels below $170 \mathrm{mg} / \mathrm{dl}$ and $42 \%$ (5 patients) had greater levels. Of the six patients with 46xx-45x karyotype, 5 (71.4\%) had hypercholesterolemia, two $(28.4 \%)$ had values lower than those described. Finally, for the 46xx-qx mosaicism none of the two patients had high total cholesterol levels (Graphic 2).

Another risk factor evaluated for cardiovascular disease was blood pressure levels (BP); only one patient $(4.7 \%)$ reported values above the $99^{\text {th }}$ percentile according to stature and age (according to stature graphic for patients diagnosed with TS); 20 patients $(95.2 \%)$ had readings within the $25^{\text {th }}$ and $90^{\text {th }}$ percentiles (Table 2).

\section{DISCUSSION}

Turner syndrome patients are exposed to different risk factors for coronary disease, like arterial hypertension, generally of early onset, and with a three times greater risk than the normal population of women; resistance to insulin, which affects $10-34 \%$ of the women with $\mathrm{TS}^{8}$ and hypercholesterolemia, shown in

girls as young as 11 years of age ${ }^{9}$ and not influenced by the type of karyotype. Of the 21 patients described in this study, only one patient reported high tension values (above the $99^{\text {th }}$ percentile for their age and stature).

Upon evaluating the lipid profile, we found high total cholesterol levels in 10 patients, corresponding to 47.6\% (two more patients had cholesterol limit values, 168 and $168.4 \mathrm{mg} / \mathrm{dl}$, respectively), which was more frequent in the group over 10 years of age; $14.2 \%$ (3 patients) presented hypertriglyceridemia; $9.5 \%(2$ patients) had HDL below $40 \mathrm{mg} / \mathrm{dl}$ and another $23.8 \%$ (5 patients) had LDL levels above $110 \mathrm{mg} / \mathrm{dl}$. These data are similar to that described by Garden et al. ${ }^{4}$, who suggested that hypercholesterolemia occurs in $50 \%$ of the women with TS (32 patients evaluated) over 21 years of age, but unlike the study by Garden et al. ${ }^{4}$, all our patients are younger than 21 years of age and the youngest patient affected in our group is eight years old, suggesting that lipid alteration begins during childhood.

It is worth mentioning the finding of a relationship between the 46xx-45x mosaicism and high levels of total cholesterol ( $57.5 \%$ of the patients), which was not found with the other mutations, and does not agree with 
Table 2

Blood pressure measurements and percentiles with relation to height and age

\begin{tabular}{|c|c|c|c|c|c|}
\hline & & Blood pressure & Is according & ight and age & \\
\hline Patient & Age & Height percentile* & Systolic BP & Diastolic BP & BP percentile \\
\hline 1 & 8 & 95 & 80 & 55 & $<p 50$ \\
\hline 2 & 8 & 50 & 90 & 50 & $<p 50$ \\
\hline 3 & 9 & $>$ p 97 & 95 & 60 & $<p 50$ \\
\hline 4 & 10 & 50 & 88 & 55 & $<p 50$ \\
\hline 5 & 11 & p 50 & 85 & 60 & $<p 50$ \\
\hline 6 & 11 & p97 & 130 & 80 & $>p 99$ \\
\hline 7 & 11 & 97 & 90 & 60 & $<p 50$ \\
\hline 8 & 12 & 90 & 105 & 62 & $<p 50$ \\
\hline 9 & 12 & 70 & 80 & 55 & $<p 50$ \\
\hline 10 & 13 & 90 & 90 & 60 & $<p 50$ \\
\hline 11 & 13 & 97 & 90 & 60 & $<p 50$ \\
\hline 12 & 14 & 95 & 90 & 60 & $<p 50$ \\
\hline 13 & 14 & 75 & 110 & 80 & $<p 50$ \\
\hline 14 & 14 & 75 & 100 & 70 & $<p 50$ \\
\hline 15 & 15 & 75 & 100 & 60 & $<p 50$ \\
\hline 16 & 15 & 75 & 110 & 70 & $50-75$ \\
\hline 17 & 16 & 95 & 90 & 60 & $<p 50$ \\
\hline 18 & 16 & 95 & 100 & 60 & $<p 50$ \\
\hline 19 & 16 & 95 & 100 & 70 & $<p 50$ \\
\hline 20 & 18 & $25-50$ & 100 & 70 & $<p 50$ \\
\hline 21 & 20 & $>$ p 97 & 110 & 70 & $<p 50$ \\
\hline
\end{tabular}

* Height percentiles measured according to graphic for patients diagnosed with Turner syndrome

that previously reported in literature ${ }^{10}$ (Graphic 2). Significant data that could serve as screening to carry out lipid profile in patients with TS with this alteration and which makes us think of the possible protective effect or of intrinsic risk according to the type of chromosomal alteration.

Also, obesity is common in women with TS and it is associated to high triglyceride and cholesterol levels, which contributes to increased cardiovascular risk ${ }^{11}$. These patients present central-type obesity with increased waist/hip index and reduced body mass free of fat ${ }^{12}$. However, in our study we found no patients with obesity; on the contrary, most of the patients described $(90.4 \%)$ had a BMI between the $3^{\text {rd }}$ and $85^{\text {th }}$ percentiles; likewise, we could not correlate high lipid profile levels with the higher BMIs. These results could be explained by early intervention of risk factors done in endocrinology consultation, which emphasizes a balanced diet and regular physical activity from the first consultation. But this must take into account the lipolytic effect of the growth hormone, used by $100 \%$ of the patients evaluated.

In our study we found no significant alteration of blood pressure levels ${ }^{7}$, contrary to most studies published on patients with TS. This leads us to think of the possible association between blood pressure levels and BMI in TS patients. But, independent of our finding, there is a clear need to assess blood pressure levels in patients with TS.

In the past, the increased prevalence of coronary disease in women with TS was considered a consequence of premature ovarian failure that caused a loss of the 
estrogen effect and increased adiposity; we found a relationship between high levels of total cholesterol and triglycerides with increased age, not evidenced with HDL and LDL levels. Our finding is interesting in that the lipid alteration predominates according to the age group, given that $90 \%$ of the patients with high levels of total cholesterol and $100 \%$ of the patients with high levels of triglycerides were over 12 years of age. These data could be useful when establishing an adequate age to conduct lipid screening in girls and adolescent females with TS. This association could also be explained by the arrival of puberty and the estrogen deficit presented by these patients. But, currently, the theory of the protective effect of the ovarian hormones in cardiac disease has lost strength ${ }^{14}$. In a study carried out by Cooley et al. ${ }^{9}$, patients with TS were compared with patients with 46xx karyotype with ovarian failure who did not receive estrogen treatment. They found that patients with Turner syndrome had higher levels of LDL cholesterol, total cholesterol, and triglycerides tan the control group, suggesting that it may be caused by haploinsufficiency of an unknown gene in the $\mathrm{X}$ chromosome that is not inactivated (this gene may contribute to the favorable lipid profile women have in comparison to men, with the second $\mathrm{X}$ chromosome somehow being cardioprotective) ${ }^{1}$. This hypothesis has gained support in recent years given that a great number of $X$ chromosome genes escape inactivation, suggesting that healthy women experience a different effect linked to the X compared, both to men and to patients diagnosed with TS, which are monosomic for the $\mathrm{X}^{6}$ chromosome. In this study, it is worth stating that patients using estrogen replacement (12 patients), eight of them had hypercholesterolemia and two had hypertriglyceridemia, which would be against the protective effect of the estrogens. Additionally, although four of the 21 patients were being treated with levothyroxine due to hypothyroidism diagnosis; all were suitably controlled given that this diagnosis does not affect cholesterol and triglyceride levels. All the aforementioned would justify similar studies in different regions of the country to establish if nutritional factors could be associated to possible lipid profile alterations in patients with TS.

In this study, the assessment of the lipid profile was done without bearing in mind growth hormone treatment ${ }^{13,14}$ (duration, age of onset, dosage), which has clear lipolytic and hypolipemiant effects that could interfere with the results. This could justify performing a lipid profile after removing the growth hormone.

\section{CONCLUSION}

In this study, we described the lipid and anthropometric profiles of a group of girls and adolescent females with TS who attended pediatric endocrinology consultation at Clínica Universitaria Bolivariana; a total of 21 patients were evaluated ranging from 8 to 20 years of age. Upon conducting the analysis, we found that their BMI was not above the normal values; however, this may be explained because they were under endocrine care, which has early intervention to control risk factors (diet, regular physical activity). We also confirmed that the patients with TS do reveal lipid profile alteration from early ages even with estrogen replacement and growth hormone treatment; although these data are only descriptive and the population group is small. Further comparative studies would be rendered with girls without the disease to determine why these patients are exposed to greater risk of dyslipidemia and, consequently, to coronary disease, and to also establish if the karyotype is an independent risk factor for said complications. As a final conclusion, when evaluating patients with TS bear in mind that they need monitoring of cardiovascular risk factors throughout their lives.

Conflict of interest. None of the authors has conflicts of interest related to this study.

\section{REFERENCES}

1. Elsheikh M, Dunger DB, Conway GS. Turner's syndrome in adulthood. Endocrine Rev. 2002; 23: 120-40.

2. Elsheikh M, Conway G. The impact of obesity on cardiovascular risk factors in Turner's syndrome. Clin Endocrinol. 1998; 49: 449-50.

3. Morgan T. Turner syndrome diagnosis and management. Am Fam Physic. 2007; 76: 405-10.

4. Kozlowska M, Jezb W, Zdrojewskic T, Chwojnickic K. Are young women with Turner's syndrome at greater risk of coronary artery disease? Euro J Cardiovasc Prev Rehabil. 2006; 13: 4679.

5. Ho V, Bakalov V, Cooley M, Van P, Hood M, Burklow T, et al. Major vascular anomalies in Turner's syndrome prevalence and magnetic resonance angiographic features. Circulation. 2004; 110: 1694-700.

6. Gravholt C, Hjerrild B, Mosekilde L, Hansen T, Rasmussen L, Frystyk $\mathrm{J}$, et al. Body composition is distinctly altered in Turner's syndrome: relations to glucose metabolism, circulating 
adipokines, and endothelial adhesion molecules. Euro $J$ Endocrinol. 2006; 155: 583-92.

7. Bondy C. Clinical practice guideline, care of girls and women with Turner syndrome: A guideline of the Turner's Syndrome Study Group. JClin Endocrinol Metabolism. 2007; 92:10-25.

8. Ross J, Feuillan P, Long L, Kowal K, Kushner H, Cutler G. Lipid abnormalities in Turner's syndrome. J Pediatr. 1994; 126: $242-5$.

9. Cooley M, Bakalov V, Bondy C. Lipid profile in women with $45 \mathrm{x}$ vs. 46xx, primary ovarian failure. JAMA. 2003; 290: 2127-8.

10. Mansoury M, Barrenäs M, Bryman I, Hanson C, Larsson C, Wilhelmsen L, et al. Chromosomal mosaicism mitigates stigmata and cardiovascular risk factors in Turner's syndrome. Clin Endocrinol. 2007; 66: 744-51.
11. Ostberg J, Hosseinzadeh M, Mohamed-Ali V, Conway G. Adipokine dysregulation in Turner's syndrome: comparison of circulating interleukin-6 and leptin concentrations with measures of adiposity and $\mathrm{C}$ reactive protein. JClin Endocrinol Metabol. 2005; 90: 2948-53.

12. Corrigan E, Nelson L, Bakalov V, Yanovski J, Vanderhoof V, Yanoff L, et al. Effects of ovarian failure and X-chromosome deletion on body composition and insulin sensitivity in young women. Menopause. 2006; 13: 911-6.

13. Van P, Bakalov V, Bondy C. Monosomy for the X-chromosome is associated with an atherogenic lipid profile. JClin Endocrinol Metabol. 2006; 91: 2867-70.

14. Baxter L, Bryant J, Cave CB, Milne R. Recombinant growth hormone for children and adolescents with Turner's syndrome. Cochrane Library 2007; 3: 1-27. 